\title{
SPERMATOTOXIC, SPERMAGGLUTINATING AND CYTOTOXIC ACTIVITIES OF GUINEA-PIG AUTOANTIBODIES TO SPERM AUTOANTIGEN T
}

\author{
FRANGINE TOULLET* AND G. A. VOISIN* \\ Centre d'Immuno-Pathologie et d'Immunologie Expérimentale de l'I.N.S.E.R.M. \\ et de l'Association Claude-Bernard, Hôpital Saint-Antoine, 75012 Paris, France
}

(Received 17th April 1973)

\begin{abstract}
Summary. Sera from guinea-pigs immunized with their own spermatozoa or with purified preparations of three different guinea-pig sperm autoantigens ( $\mathrm{S}, \mathrm{P}$ and $\mathrm{T}$ ) were tested for their spermatotoxic and cytotoxic (towards immature sperm cells) properties in the presence of complement, as well as for their spermagglutinating properties. Autoimmune and anti-T sera exhibited the three properties with a high degree of tridimensional correlation. Anti-S and anti-P sera did not exhibit any of the three properties. The three properties could be specifically absorbed by $\mathrm{T}$ but not by $\mathrm{S}$ or $\mathrm{P}$ autoantigens. While $\mathrm{P} /$ anti-P and $T /$ anti- $T$ are both complement-fixing systems, only $T$ is present at the cell surface and only anti-T will fix on living sperm cells. The biological and immunopathological consequences of the preceding results are discussed in relation to the ability of each one of the three sperm autoantigens to induce an autoimmune aspermatogenic orchitis.
\end{abstract}

\section{INTRODUCTION}

Four autoantigens are known to be present in guinea-pig spermatozoa; they have been termed S, P, T and Z (Voisin \& Toullet, 1968). Three of them, S, $\mathbf{P}$ and $\mathrm{T}$, have been separated and studied for their physicochemical and immunological properties (Voisin \& Toullet, 1968, 1969a; Toullet \& Voisin, 1969) as well as for their cytological localization (Toullet, Voisin \& Nemirovsky, 1970,1973 ). Each one of these three autoantigens, when injected together with complete Freund's adjuvant to male guinea-pigs, induces autoimmune aspermatogenic orchitis (AIAO) with skin hypersensitivity of various types and autoantibodies specific for the injected antigen (Voisin \& Toullet, 1968, $1969 \mathrm{~b})$. Antigen-antibody reactions in vitro differ according to the autoantigen involved. Only anti-T antibodies are able to fix complement with sperminsoluble extract and to kill spermatozoa in the presence of complement. Anti-P antibodies fix complement with sperm-soluble extracts exclusively and are not spermatotoxic.

The purpose of the present study was threefold: (1) to ascertain with a variety of sera the fact that only anti-T antibodies are spermatotoxic, (2) to compare the spermatotoxic and spermagglutinating activities, (3) to compare both of the

* Associated Team to the National Center of Scientific Research (CNRS-ERA 149). 
preceding activities to the cytotoxic activity towards immature germinal cells that have been shown to contain autoantigen $\mathrm{T}$, and some of which also contain $\mathrm{S}$ and $\mathrm{P}$ (Toullet et al., 1973).

\section{MATERIALS AND METHODS}

Hartley guinea-pigs, 450 to $600 \mathrm{~g}$, were utilized both as a source of spermatozoa and testicular cells and of autoantibody-containing sera after immunization (of intact or castrated animals).

The autoantigens included the following: autologous ground spermatozoa and autoantigens $\mathrm{S}, \mathrm{P}$ or $\mathrm{T}$. These were prepared according to a method which has been described (Voisin \& Toullet, 1969a; Toullet et al., 1973). Briefly, guinea-pig spermatozoa obtained by epididymal retroperfusion with distilled water are ground and submitted to slow centrifugation (500 $\mathrm{g}$ for $20 \mathrm{~min}$ at $4^{\circ} \mathrm{C}$ ) and the sediment is discarded. The supernatant is submitted to a second, fast centrifugation $\left(80,000 \mathrm{~g}\right.$ for $30 \mathrm{~min}$ at $\left.4^{\circ} \mathrm{C}\right)$. The 'fast' supernatant or soluble extract contains S- and P-soluble autoantigens and the 'fast' sediment contains insoluble $\mathrm{T}$. These three autoantigens are then purified: 3 vols of soluble extract are treated with 1 vol of $20 \%$ trichloracetic acid (TCA) and centrifuged $\left(80,000 \mathrm{~g}\right.$ for $30 \mathrm{~min}$ at $\left.4^{\circ} \mathrm{C}\right)$. The supernatant or TCA-soluble extract contains autoantigen $S$ (and small amounts of $P$ ); it is neutralized, dialysed, concentrated and filtered on G-100 Sephadex that yields $\mathrm{S}$ in the excluded fractions. The sediment or TCA-insoluble extract containing autoantigen $\mathbf{P}$ (and small amounts of $\mathbf{S}$ ) is neutralized, dissolved in water and treated with chloroform-butanol to eliminate chloroform-precipitated proteins. After centrifugation, the P-containing aqueous supernatant is dialysed, concentrated and filtered on G-100 Sephadex that yields $P$ in the included fractions. These two autoantigens, $\mathrm{S}$ and $\mathrm{P}$, kept in solution at $-20^{\circ} \mathrm{C}$ or freeze-dried, maintain their properties during months and even years. Autoantigen $\mathrm{T}$ is obtained from the fast sediment after sonication (MSE Mullard $20 \mathrm{kHz}$ ) for $5 \mathrm{~min}$; the insoluble part is washed five times in distilled water and resuspended in phosphate-buffered saline (PBS).

The antigenic activity of the three preaprations, $\mathrm{S}, \mathrm{P}$, and $\mathrm{T}$, was quantified by reference to the intensity of the specific serological reactivity of the extracts as compared with standard reference preparations (whole spermatozoa-for $\mathrm{T}$ -or whole spermatozoa aqueous crude extract--for $S$ and $P$ ) when tested against autoantibody-containing standard reference sera. The serological tests utilized were complement fixation for $\mathrm{T}$, passive haemagglutination inhibition for $S$ and Mancini's radial immunodiffusion, or passive haemagglutination inhibition, for $\mathrm{P}$. The quantity of autoantigen present in a given preparation was therefore expressed as equivalent $(\bumpeq)$ to the number of spermatozoa contained in the standard reference preparation giving the same serological activity.

Autoantibody-containing sera were prepared in intact or castrated guineapigs. Intact animals were given only one antigen injection ( $S, P$ or $T$ ) in an amount $\bumpeq 10^{8}$ spermatozoa in complete Freund's adjuvant (Difco) injected into the hind-foot pads. Serum was withdrawn 1 to 8 weeks later. Castrated animals received a single first injection of autologous spermatozoa or of autoantigens 
$\mathrm{S}, \mathrm{P}$ to $\mathrm{T}$ as above, followed by three subcutaneous or intradermal injections without adjuvant at monthly intervals $\left(2 \times 10^{7}\right.$ for the first two and $10^{8}$ for the last one). Blood was withdrawn 6 to 7 days after the last injection. The sera were kept at $-20^{\circ} \mathrm{C}$. They contained the following properties tested against specific antigens or whole spermatozoa. Anti-S sera were anaphylactic (PCA), non-precipitating (Ouchterlony), haemagglutinating S-sensitized sheep red blood cells, not (or almost not) haemolytic, and not (or almost not) complementfixing. Anti-P sera were anaphylactic, precipitating, haemagglutinating Psensitized sheep red blood cells, haemolytic in the presence of complement for the same cells and strongly complement-fixing. Anti-T sera did fix complement and were spermatotoxic. In view of the insolubility of the $T$ preparations, other reactions cannot be tested. Anti-autospermatozoa sera exhibited at various titres the properties of anti-S, anti-P and anti-T sera; they had been kept longerfor years-than the three other sera. Sera from male guinea-pigs either untreated or having received complete Freund's adjuvant emulsions with saline or bovine serum albumin or dinitrophenol-bovine $\gamma$-globulin were used as controls.

Complement was prepared in our laboratory from normal guinea-pig sera kept at $-180^{\circ} \mathrm{C}$ in small fractions and regularly checked. The titre was 180 to $200(50 \%)$ haemolytic units per $\mathrm{ml}$.

Eagle's medium was obtained from Serpasteur, Paris, and freeze-dried heparin from Choay.

The methods used were concerned with spermatotoxicity, spermagglutination and cytotoxicity techniques. In all cases, the sera were heated for $30 \mathrm{~min}$ in a water-bath at $56^{\circ} \mathrm{C}$ and epididymal spermatozoa or testicular cells were obtained from exsanguinated adult Hartley guinea-pigs.

\section{Spermatotoxicity}

Epididymal spermatozoa were obtained by retroperfusion of the ductus deferens and epididymis of a guinea-pig with PBS. The sperm concentration was adjusted to $10^{7} / \mathrm{ml}$. Amounts $(0 \cdot 1 \mathrm{ml})$ of doubling dilutions starting from $1 / 2$ of the serum being tested, $0.1 \mathrm{ml}$ sperm suspension and $0.02 \mathrm{ml}$ undiluted complement were mixed in a test-tube. After $15 \mathrm{~min}$ in a water-bath at $37^{\circ} \mathrm{C}$, one drop of the mixture was examined between a slide and a cover-slip with a phase-contrast microscope (objectives 10 and 25, ocular $\times 10$ ). The technique could also be utilized on titration plates with smaller quantities without modification of the reaction: serum dilutions $0.025 \mathrm{ml}$, sperm suspension $0.025 \mathrm{ml}$ and $1 / 5$ diluted complement $0.025 \mathrm{ml}$; the mixture was incubated for $25 \mathrm{~min}$ at $37^{\circ} \mathrm{C}$. Control preparations included normal sera plus normal complement and autoantibody-containing sera plus heated complement $\left(56^{\circ} \mathrm{C}\right.$ for $\left.30 \mathrm{~min}\right)$. Spermatozoa were examined for their motility and for the presence or absence of an acrosome (Pl. 1, Figs 1A and B). Absence of motility did not necessarily indicate that death had occurred since guinea-pig spermatozoa kept for $1 \mathrm{hr}$ in PBS became immotile but resumed motility when serum was added. This examination was always done blindly.

\section{Spermagglutination}

Sera were diluted on titration plates in heated normal guinea-pig serum diluted 
$1 / 50$. Spermatozoa obtained as above were adjusted to $2 \times 10^{6} / \mathrm{ml}$ PBS or to $1 \cdot 0$ absorption at $280 \mathrm{~nm}$ on a Beckman spectrophotometer. Sperm suspension $(0.025 \mathrm{ml})$ was added to serum dilutions $(0.025 \mathrm{ml})$. The reactions were read with a magnifying glass after $1 \mathrm{hr}$ at room temperature and after one night at $+4^{\circ} \mathrm{C}$. The results are shown in $\mathrm{Pl}$. 1, Fig. 2. In negative reactions, the spermatozoa formed a smooth layer on the bottom of the microplate wells, with an occasional small central button. This represented a normal microagglutination that was always seen when guinea-pig spermatozoa were placed in guinea-pig serum and even sometimes in PBS alone (it corresponded, microscopically, to small head-to-head agglutination with many non-agglutinated cells). The positive reactions were rated ' +++ ' for very strong agglutination with all the spermatozoa sticking together and gathered in the bottom as an irregular mass; microscopically, all the spermatozoa were part of a huge mass consisting of head-to-head clusters linked in a network by tail-to-tail and head-to-tail agglutination. The rating ' ++ ' was applied where several smaller masses were seen. A single ' + ' indicated clusters which were smaller but easily seen with the magnifying glass; microscopically, many clusters were seen which were not united in a network. A few non-agglutinated individual spermatozoa were seen. The quantity and density of spermatozoa utilized was of prime importance. With the preceding technique, the appreciation of the results became impossible with less than $10^{6}$ or more than $4 \times 10^{6}$ spermatozoa.

\section{Cytotoxicity}

Sera were diluted in Eagle's medium. Testicular cells were prepared as follows. After removal of the tunica albuginea, the testis was placed in heparinized (1 unit $/ \mathrm{ml}$ ) Eagle's medium, and minced with scissors allowing cell dissociation. The resulting suspension was filtered on gauze, centrifuged (130 $\mathrm{g}$ for $4 \mathrm{~min}$ ) and washed once. The cells were finally suspended in Eagle's medium at concentration of $10^{7} \mathrm{cells} / \mathrm{ml}$. A $0 \cdot 1 \mathrm{ml}$ vol of the cell suspension was added to $0.1 \mathrm{ml}$ of serum doubling dilutions and $0.02 \mathrm{ml}$ complement. After incubation in a $37^{\circ} \mathrm{C}$ water-bath for $1 \mathrm{hr}$, each tube received $0.2 \mathrm{ml}$ of a $0.194 \%$ trypan blue dilution in saline and $3 \mathrm{~min}$ later the percentages of 'dead' (blue and grey) and 'living' (bright, not blue) cells were read between slide and cover-slip. At least 100 cells were counted per preparation. Controls consisted of preparations where the complement had been heated before use or where fresh complement was utilized alone without immune serum. The final percentage of specifically killed cells was given by the formula:

$$
\frac{\% \text { dead cells in experimental }-\% \text { dead cells in control }}{100-\% \text { dead cells in control }} \times 100
$$

\section{Absorption tests}

These were performed for spermatotoxic, spermagglutinating and cytotoxic activities of the studied sera. Autoantibody-containing sera and control sera, were incubated for $1 \mathrm{hr}$ at $37^{\circ} \mathrm{C}$ and overnight at $+4^{\circ} \mathrm{C}$ with various tissue or cell preparations (or without any preparation) and then centrifuged at $45,000 \mathrm{~g}$ for $1 \mathrm{hr}$ at $4^{\circ} \mathrm{C}$. The quantification of absorbing preparations was expressed in 


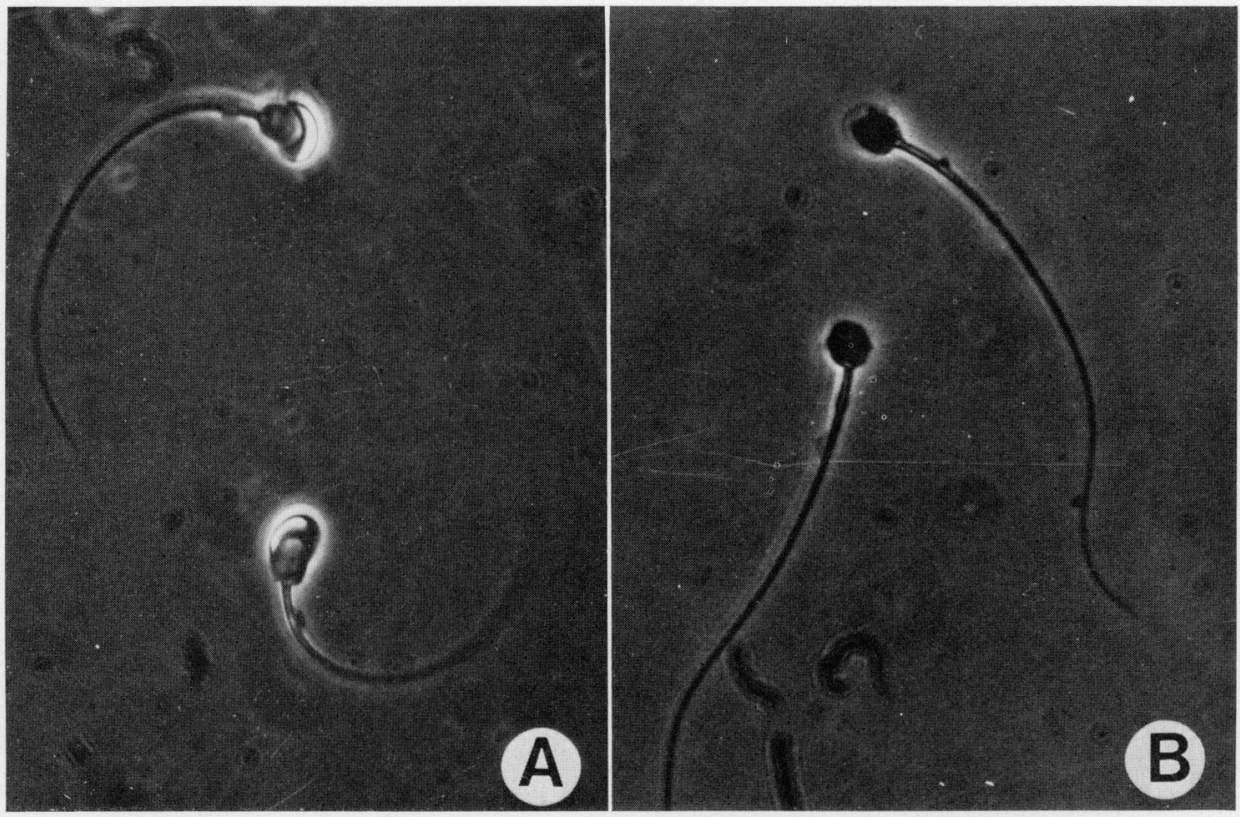

Fir. 1. Plase-contrast microseopy of guinea-pig spermatozoa. (A live motile spermatozoa showing the presence of bright arrosomes. (B) Dead immolile spermatozoa without acrosomes $(\times 560)$.

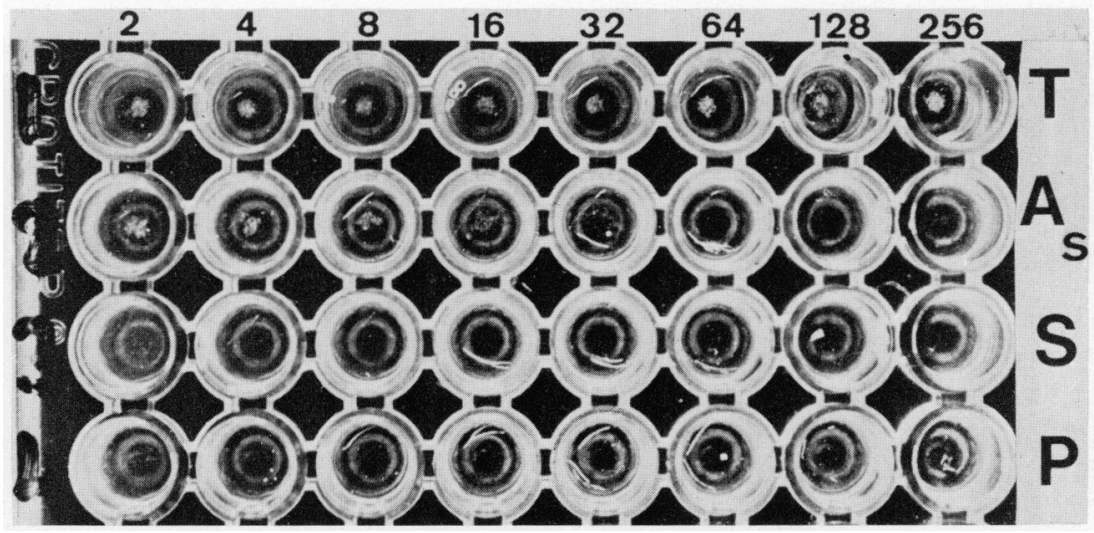

Fir: 2. Agglutination of guinea-pig spernatozoa by antibolies 0 antoantigen $T$ in microplate. Fon inmume sera doubling dilutions were placed in microplate wells: $\mathrm{I}^{\prime}=$ anti-atuoantigen $\mathrm{l}: \mathrm{S}=$ anti-aubologous whole spematoma; $\mathrm{S}=$ anti-autoantigen $\mathrm{S}: \mathrm{P}=$ anti-atuloantigen $\mathrm{P}$. The number at the top is the clilution of the immune sera. The agghtinated spermatozoa formed small white centrat spests in the bottom of the

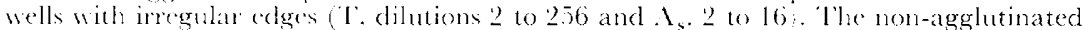
spermatozoa formed a large mat mot visible in the photographsis. The peripheral white rings present in all the wells are due to the reflected light and bear no relation to the arrangement of the spermaltomas. 
terms of equivalent $(\bumpeq)$ numbers of spermatozoa for autoantigen-containing preparations or of cell number (for spleen preparations) or of wet weight in $g$ (for other tissues homogenate preparations). In all cases, the given quantity was incubated with $0 \cdot 1 \mathrm{ml}$ pure studied serum. The studied preparations were: guinea-pig ground spermatozoa $1.5 \times 10^{5}$ to $3.9 \times 10^{9}$; freeze-dried crude soluble sperm extract $\bumpeq 2 \times 10^{7}$ to $2.4 \times 10^{9}$ spermatozoa; freeze-dried autoantigen $\mathrm{S} \bumpeq 8 \times 10^{8}$ to $1.5 \times 10^{10}$ spermatozoa; freeze-dried autoantigen $\mathrm{P}$ $\bumpeq 1.6 \times 10^{9}$ to $1.6 \times 10^{10}$ spermatozoa; autoantigen $\mathrm{T}, 1.2 \times 10^{7}$ to $1.6 \times 10^{10}$ spermatozoa ; testis homogenate, $1 \mathrm{~g}$; liver homogenate, $1 \mathrm{~g}$; kidney homogenate, $1 \mathrm{~g}$; ground spleen cells, $10^{9}$.

\section{RESULTS}

\section{Spermatotoxicity}

Freshly removed guinea-pig epididymal spermatozoa were always highly motile. There were usually less than $10 \%$ dead spermatozoa (without an acrosome) after 1 to $2 \mathrm{hr}$ at laboratory temperature. If the spermatozoa were poorly motile or if the number of dead spermatozoa exceeded $10 \%$, the preparation was discarded. Adding complement without immune serum to the preparation did not increase the number of dead spermatozoa. Immune serum added to the preparation with heated complement $\left(30 \mathrm{~min}\right.$ at $\left.56^{\circ} \mathrm{C}\right)$ did not affect sperm survival.

The dilutions of immune sera spermatotoxic at a $100 \%$ level were studied by doubling up to the dilution that gave no spermatotoxicity. No prozone phenomenon was observed. When a serum was spermatotoxic at high dilution ( 500 for instance), it always gave $100 \%$ spermatotoxicity at the lowest dilutions. The dilution that gave $50 \%$ (or a little over) specifically killed cells was chosen as the spermatotoxic titre $(50 \%)$.

The results expressed in Table 1 concern over 700 sera. They show that spermatotoxic properties were exhibited by anti-whole autospermatozoa sera and anti-T sera and only by these two types. Anti-S and anti-P sera exhibited no spermatotoxicity.

These results $(0 \%$ with $S$ and $P$ versus $100 \%$ with $T$ ) necessitated the use of castrated guinea-pigs (or females) in order to eliminate endogeneous sources of autoantigens (Table 1, upper part). When utilizing intact males, only $\mathrm{T}$ induced spermatotoxic titres $>16^{-1}$. Following an injection of $S$ and $P$, however, a weak spermatotoxic titre was noted in a proportion of the sera (Table 1, lower part). Most of these animals exhibited testicular lesions (autoimmune aspermatogenic orchitis) that might be expected to release $T$ autoantigens. It was verified that immunization with $\mathrm{T}$ without adjuvants was able to lead to the production of spermatotoxic sera in six out of six animals (titre 8 to 32).

Only antigen $\mathrm{T}$ and (antigen $\mathrm{T}$-containing) autologous spermatozoa, therefore, were able to induce the formation of spermatotoxic antibodies.

Spermatotoxic antibodies were detected (titre often around 8) as early as Day 6 after the first immunizing injection. On Day 7, the titre was often around 32. It frequently increased afterwards and, after several antigen injections, might reach 500 (usually 100). The kinetics of the spermatotoxic process were 
Table 1. Spermatotoxic activity of guinea-pig sera after immunization with sperm autoantigens

\begin{tabular}{|c|c|c|c|c|c|c|c|c|c|c|c|}
\hline \multirow{2}{*}{$\begin{array}{c}\text { Immunizing } \\
\text { antigens } \\
\text { plus } C F A\end{array}$} & \multicolumn{9}{|c|}{ No. of sera giving the indicated spermatotoxic titre* } & \multirow{2}{*}{$\begin{array}{c}\text { No. of } \\
\text { studied } \\
\text { sera }\end{array}$} & \multirow{2}{*}{$\underset{\%}{\%}$} \\
\hline & $\leqslant 2 \dagger$ & 4 & 8 & 16 & 32 & 50 & 100 & 200 & $\geqslant 400$ & & \\
\hline $\begin{array}{l}\text { Castrated male } \\
\text { guinea-pigs } \ddagger \\
\mathbf{S} \\
\mathrm{P} \\
\mathrm{T} \\
\text { Autologous } \\
\text { spermatozoa }\end{array}$ & $\begin{array}{r}206 \\
80 \\
\\
23\end{array}$ & $\begin{array}{l}-\Phi \\
- \\
10\end{array}$ & $\begin{array}{l}\overline{-} \\
\frac{-}{19}\end{array}$ & $\begin{array}{c}\overline{-} \\
1 \\
7\end{array}$ & $\begin{array}{l}\bar{Z} \\
1 \\
21\end{array}$ & $\begin{array}{l}\overline{-} \\
12 \\
-\end{array}$ & $\begin{array}{l}\overline{-} \\
18 \\
22\end{array}$ & $\begin{array}{l}- \\
- \\
-\end{array}$ & $\begin{array}{r}\overline{-} \\
15 \\
5\end{array}$ & $\begin{array}{r}206 \\
80 \\
50 \\
\\
107\end{array}$ & $\begin{array}{r}0 \\
0 \\
100 \\
\\
78.5\end{array}$ \\
\hline $\begin{array}{l}\text { Intact male } \\
\text { guinea-pigs } \$ \\
\text { No injection } \\
\text { Saline } \\
\text { S } \\
\mathrm{P} \\
\mathrm{T}\end{array}$ & $\begin{array}{r}129 \\
70 \\
3 \\
7 \\
4\end{array}$ & $\begin{array}{l}\text { 二 } \\
1 \\
2 \\
1\end{array}$ & $\begin{array}{c}- \\
\overline{6} \\
1 \\
2\end{array}$ & $\begin{array}{c}- \\
\overline{-} \\
3 \\
7\end{array}$ & $\begin{array}{l}\bar{Z} \\
\overline{4}\end{array}$ & $\begin{array}{l}\bar{Z} \\
\overline{7}\end{array}$ & $\begin{array}{l}\bar{Z} \\
\overline{3}\end{array}$ & $\begin{array}{l}\bar{Z} \\
\overline{6}\end{array}$ & $\begin{array}{l}- \\
\frac{-}{3}\end{array}$ & $\begin{array}{r}129 \\
70 \\
10 \\
13 \\
39\end{array}$ & $\begin{array}{l}0 \\
0 \\
70 \\
46 \cdot 15 \\
89.7\end{array}$ \\
\hline
\end{tabular}

* Reverse of titre.

+ Considered as negative.

\$The castrated guinea-pigs received one injection of antigen plus CFA and two or three injections of antigen in saline.

$\$$ The intact immunized guinea-pigs received a single immunizing injection of antigen plus CFA.

If Absence of data indicates that no case was observed with the corresponding titres.

followed by examinations made after $5,7,10$ and 15 min of sperm incubation with an anti-T serum (100\% spermatotoxic at the dilution utilized) plus complement at $37^{\circ} \mathrm{C}$. At $5 \mathrm{~min}$, most of the spermatozoa were immotile but possessed acrosomes. At $7 \mathrm{~min}$, all the spermatozoa were immotile, and some had lost their acrosomes. At 10 and $15 \mathrm{~min}$, all the spermatozoa were immotile and lacked acrosomes. Such dead spermatozoa were never agglutinated.

\section{Spermagglutination}

We devised and set up this technique more recently than the spermatotoxic test. The number of studied sera (160) was, therefore, not as large. As seen in Table 2, the spermagglutinating property belonged to anti-T as well as to anti-autospermatozoa sera. The reproducibility of this test was excellent. No spermagglutination was observed if there was complement in the medium. Spermagglutinating activity appeared on Day 11 only after previous immunization with T. After three to four injections, the titre usually reached 32 to 64 . The maximum observed titre was 256. In the absence of Freund's adjuvant, and after four antigen injections, four out of six guinea-pigs had very weak titres of spermagglutinating antibodies.

A small percentage of anti-S and especially of anti-P sera were spermagglutinating at weak dilutions (never over 4 to 8 ). Intact animals did not seem to make more spermagglutinating antibodies than castrated ones.

\section{Cytotoxicity}

Since isolated testicular cells (essentially immature sperm cells) are very 
fragile, the conditions of cytotoxicity studied must be very carefully controlled. With preparations containing heated complement plus guinea-pig sera (either immune or normal, but always heated), a mean of $9.2 \%$ cell death (range 4 to 16 ; median 9.5 ) was found. In $80 \%$ of the studied cases, the percentage of cell death was less than $12 \%$. With preparations containing only heated complement in the medium (without additional serum), a mean of $7.3 \%$ cell death (range 4 to 11 ; median 8 ) was found. With preparations containing unheated, active complement (without antibodies), however, the mean percentage of cell death was higher: $13 \%$ (range 4 to 42 ; median 11 ), though $80 \%$ of the figures were below $14 \%$. Although these relatively high figures were never seen when additional serum (even diluted up to $80^{-1}$ ) was present in the medium, it was

Table 2. Spermagglutinating activity of guinea-pig sera after immunization with sperm autoantigens

\begin{tabular}{|c|c|c|c|c|c|c|c|c|c|c|}
\hline \multirow{2}{*}{$\begin{array}{l}\text { Immunizing } \\
\text { antigens } \\
\text { plus CFA }\end{array}$} & \multicolumn{8}{|c|}{ No. of sera giving the indicated spermagglutinating titre* } & \multirow{2}{*}{$\begin{array}{c}\text { No. of } \\
\text { studied } \\
\text { sera }\end{array}$} & \multirow{2}{*}{$\stackrel{\%}{\%}$} \\
\hline & $\leqslant 2$ & 4 & 8 & 16 & 32 & 64 & 128 & 256 & & \\
\hline $\begin{array}{l}\text { Castrated } \\
\text { male guinea-pigs } \dagger \\
\mathbf{S} \\
\mathbf{P} \\
\mathrm{T} \\
\text { Autologous } \\
\text { spermatozoa }\end{array}$ & $\begin{array}{r}38 \\
\frac{33}{2}\end{array}$ & $\begin{array}{r}1 \\
4 \\
6\end{array}$ & $\begin{array}{c}-\$ \\
1 \\
2 \\
2\end{array}$ & $\begin{array}{r}- \\
\frac{1}{4}\end{array}$ & $\begin{array}{c}\overline{4} \\
2\end{array}$ & $\frac{\bar{Z}}{2}$ & $\overline{-}$ & $\overline{5}$ & $\begin{array}{l}39 \\
38 \\
16 \\
19\end{array}$ & $\begin{array}{c}2 \cdot 6 \\
13 \cdot 1 \\
100 \\
89 \cdot 4\end{array}$ \\
\hline $\begin{array}{l}\text { Intact male } \\
\text { guinea-pigs } \ddagger \\
\text { No injection } \\
\text { Saline } \\
\text { S } \\
\text { P } \\
\mathrm{T}\end{array}$ & $\begin{array}{r}14 \\
12 \\
1 \\
4\end{array}$ & $\frac{\overline{-}}{\frac{1}{6}}$ & $\frac{\bar{Z}}{\bar{z}}$ & $\begin{array}{c}\bar{z} \\
\overline{3}\end{array}$ & $\begin{array}{l}\bar{z} \\
\overline{1}\end{array}$ & $\begin{array}{l}\bar{z} \\
\overline{1}\end{array}$ & $\begin{array}{l}\bar{Z} \\
\overline{1}\end{array}$ & $\begin{array}{l}\bar{z} \\
\overline{1}\end{array}$ & $\begin{array}{r}14 \\
12 \\
2 \\
0 \\
20\end{array}$ & $\begin{array}{c}0 \\
0 \\
(50) \\
80\end{array}$ \\
\hline
\end{tabular}

* Reverse of titre.

$\uparrow$ The castrated guinea-pigs received one injection of antigen plus CFA and two or three injections of antigen in saline.

$\ddagger$ The intact immunized guinea-pigs received one immunizing injection of antigen plus CFA.

$\S$ Absence of data indicates that no case was observed with the corresponding titres.

decided to take the figures obtained with active complement alone as the controls and to discard the testicular cell preparations (and cancel the experiment) whenever the percentage of dead cells exceed 16\% (20 to 42) with active complement alone. Once these preparations $(15 \%$ of the cases) were excluded, the mean percentage of cell death became 9.6 (range 4 to 16 ; median 10) which was comparable to the levels for the other controls but with the additional advantage of utilizing more resistant cell preparations. Moreover, the only sera considered as being positive, i.e. cytotoxic, were the ones giving a final percentage of specifically killed cells (see 'Materials and Methods') that was $\geqslant 11 \%$ (as a mean, this was twice as much as the control level of cell death). Anti-T serum never gave a figure which was lower than that of the controls. The results are expressed here as the last serum dilution giving the required cytotoxic activity $(>11 \%)$. This is the cytotoxic titre.

Under these very strict conditions, it can be seen (Table 3 ) that practically 
only sera from animals immunized with $\mathrm{T}$ or autologous spermatozoa were cytotoxic for testicular cells. This becomes even clearer when considering castrated hyperimmunized animals where $100 \%$ of anti-T sera had a cytotoxic titre which was $\geqslant 4^{-1}$, while the corresponding figures were $0 \%$ with $\mathrm{P}$ and $3.8 \%$ with S.

The percentage of dead cells decreased with the dilution (the highest positive dilution having been $80^{-1}$ with $28 \%$ specifically killed cells). It increased with decreasing dilutions, without a noted prozone phenomenon, up to a maximum of $95 \%$ specifically killed cells (for $2^{-1}$ as well as $8^{-1}$ serum dilutions). This

Table 3. Cytotoxic activity of guinea-pig sera after immunization with sperm autoantigens

\begin{tabular}{|c|c|c|c|c|c|c|c|c|}
\hline \multirow{2}{*}{$\begin{array}{c}\text { Immunizing } \\
\text { antigens } \\
\text { plus } C F A\end{array}$} & \multicolumn{6}{|c|}{ No. of sera giving the indicated cytotoxic titre* } & \multirow{2}{*}{$\begin{array}{c}\text { No. of } \\
\text { studied } \\
\text { sera }\end{array}$} & \multirow{2}{*}{$\stackrel{\%}{\%}$} \\
\hline & $\leqslant 2$ & 4 & 10 & 20 & 40 & 80 & & \\
\hline $\begin{array}{l}\text { Castrated } \\
\text { male guinea-pigs } \dagger \\
\mathbf{S} \\
\mathbf{P} \\
\mathrm{T} \\
\text { Autologous } \\
\text { spermatozoa }\end{array}$ & $\begin{array}{r}25 \\
23 \\
- \\
8\end{array}$ & $\frac{1}{2}$ & $\begin{array}{c}-5 \\
\frac{3}{3}\end{array}$ & $\begin{array}{r}- \\
1 \\
6\end{array}$ & $\begin{array}{c}- \\
7 \\
1\end{array}$ & $\frac{-}{5}$ & $\begin{array}{l}26 \\
23 \\
18 \\
\\
21\end{array}$ & $\begin{array}{c}3.84 \\
0 \\
100 \\
61.8\end{array}$ \\
\hline $\begin{array}{l}\text { Intact } \\
\text { male guinea-pigs } \ddagger \\
\text { No injection } \\
\text { Saline } \\
\text { S } \\
\text { P } \\
\text { T }\end{array}$ & $\begin{array}{r}13 \\
14 \\
4 \\
1 \\
4\end{array}$ & $\begin{array}{l}\overline{1} \\
\overline{-}\end{array}$ & $\begin{array}{l}- \\
\frac{z}{3}\end{array}$ & $\begin{array}{l}- \\
\frac{Z}{4}\end{array}$ & $\begin{array}{l}- \\
\overline{7}\end{array}$ & $\begin{array}{l}- \\
z \\
-\end{array}$ & $\begin{array}{r}13 \\
15 \\
4 \\
1 \\
18\end{array}$ & $\begin{array}{l}0 \\
6 \cdot 7 \\
0 \\
0 \\
77 \cdot 7\end{array}$ \\
\hline
\end{tabular}

* Reverse of titre.

† The castrated guinea-pigs received one injection of antigen plus CFA and two or three injections of antigen in saline. CFA.

$\ddagger$ The intact immunized guinea-pigs received one immunizing injection of antigen plus

$\S$ Absence of data indicates that no case was observed with the corresponding titres.

indicates that $5 \%$ of the cells were not sensitive to the cytotoxic action of anti-T sera plus complement. Under the phase-contrast microscope, the spermatids could easily be identified from their bright acrosomes (whenever they were still present among the dead cells). In the haematein-eosin stained smears of the initial preparations, spermatids were the most numerous with a small proportion of very fragile, often altered, spermatocytes and rare spermatogonia. Electron microscopic examination of cell preparations incubated for $10 \mathrm{~min}$ with anti-T serum and complement showed that the only intact cells were Sertoli cells.

During the course of immunization, low titres of cytotoxic antibodies appeared in the serum between 8 and 11 days after the first injection. They usually reached their maximum titre in the 3 rd to 4 th week.

\section{Absorption experiments}

These have been performed for spermatotoxic, spermagglutinating and 
cytotoxic antibody properties specifically induced by sperm autoantigens. Since the preceding results strongly suggested that anti- $T$ antibodies were responsible for these three properties, an attempt was made to achieve the specific removal of the antibodies from seven anti-T sera and three pools of antiautospermatozoa sera, by preincubating the sera with various preparations.

Table 4. Spermatotoxic, spermagglutinating and cytotoxic activities of guinea-pig anti-autoantigen $\mathrm{T}$ immune serum after incubation with different quantities of autoantigen $T$

\begin{tabular}{|c|c|c|c|c|}
\hline \multirow{2}{*}{ Test } & \multirow{2}{*}{$\begin{array}{c}\text { Serum } \\
\text { dilution }\end{array}$} & \multicolumn{3}{|c|}{$\begin{array}{l}\text { Serum activity after incubation with } \\
\text { the following quantities of autoantigen } T\end{array}$} \\
\hline & & 0 & $\bumpeq 10^{9}$ sperm. & $\bumpeq 1.6 \times 10^{10}$ sperm. \\
\hline Spermatotoxicity & $\begin{array}{r}50 \\
100 \\
200 \\
400 \\
800\end{array}$ & $\begin{array}{l}100^{*} \\
100 \\
100 \\
100 \\
50\end{array}$ & $\begin{array}{r}100 \\
100 \\
100 \\
66\end{array}$ & $\begin{array}{l}0 \\
0 \\
0 \\
0\end{array}$ \\
\hline Spermagglutination & $\begin{array}{r}16 \\
32 \\
64 \\
128 \\
256 \\
512\end{array}$ & $\begin{array}{l}+\dagger \\
+ \\
+ \\
+ \\
+ \\
-\end{array}$ & $\begin{array}{l}+ \\
+ \\
+ \\
+ \\
- \\
-\end{array}$ & $\begin{array}{l} \pm \\
- \\
- \\
-\end{array}$ \\
\hline Cytotoxicity & $\begin{array}{l}10 \\
40 \\
80\end{array}$ & $\begin{array}{l}70 \ddagger \\
35 \\
28\end{array}$ & $\begin{array}{l}0 \\
0\end{array}$ & \\
\hline
\end{tabular}

* Percentage of dead spermatozoa.

† Presence $(+)$ or absence $(-)$ of spermagglutination.

$¥$ Percentage of specifically dead testicular cells.

Table 5. Relation between spermatotoxic, spermagglutinating and cytotoxic properties of guinea-pig autoantibodies

\begin{tabular}{|c|c|c|c|c|}
\hline \multirow{2}{*}{$\begin{array}{c}\text { No. of } \\
\text { simultaneous } \\
\text { properties }\end{array}$} & \multicolumn{3}{|c|}{$\begin{array}{c}\text { Presence in the studied sera of the following } \\
\text { properties }\end{array}$} & \multirow{2}{*}{$\begin{array}{l}\text { No. of sera } \\
\text { in the described } \\
\text { situation }\end{array}$} \\
\hline & Spermatotoxicity & Cytotoxicity & Spermagglutination & \\
\hline 3 & + & + & + & 28 \\
\hline 2 & $\frac{+}{t}$ & $\begin{array}{l}+ \\
+ \\
-\end{array}$ & $\begin{array}{l}- \\
+ \\
t\end{array}$ & $\begin{array}{l}1 \\
0 \\
0\end{array}$ \\
\hline 1 & $\begin{array}{l}+ \\
-\end{array}$ & $\underline{+}$ & $\overline{-}$ & $\begin{array}{l}4 \\
0 \\
0\end{array}$ \\
\hline
\end{tabular}

The results were clearcut.

(a) Complete absorption of the three activities was obtained with the following preparations: ground whole spermatozoa $\left(1.6 \times 10^{7}\right.$ to $\left.6.9 \times 10^{9}\right)$; testis homogenate $(1 \mathrm{~g})$; autoantigen $\mathrm{T}\left(\bumpeq 3.9 \times 10^{8}\right.$ to $\left.1.6 \times 10^{10}\right)$.

(b) Partial or no absorption (with some quantitative difference in the three properties) was obtained with the preceding preparations at lower doses: 
ground spermatozoa $\left(1.6 \times 10^{5}\right.$ to $\left.6.4 \times 10^{6}\right)$; autoantigen $\mathrm{T}\left(1.2 \times 10^{7}\right.$ to $\left.6 \cdot 4 \times 10^{7}\right)$. The highest dose $\left(2.4 \times 10^{9}\right)$ of several crude soluble extracts also gave a partial absorption. This can be understood since autoantigen $T$ can be solubilized to a very slight extent and, therefore, may be present in crude soluble extracts.

(c) No absorption of any of the three autoantibody activities was obtained with the following preparations: autoantigens $\mathrm{S}$ and $\mathrm{P}$ even at the highest

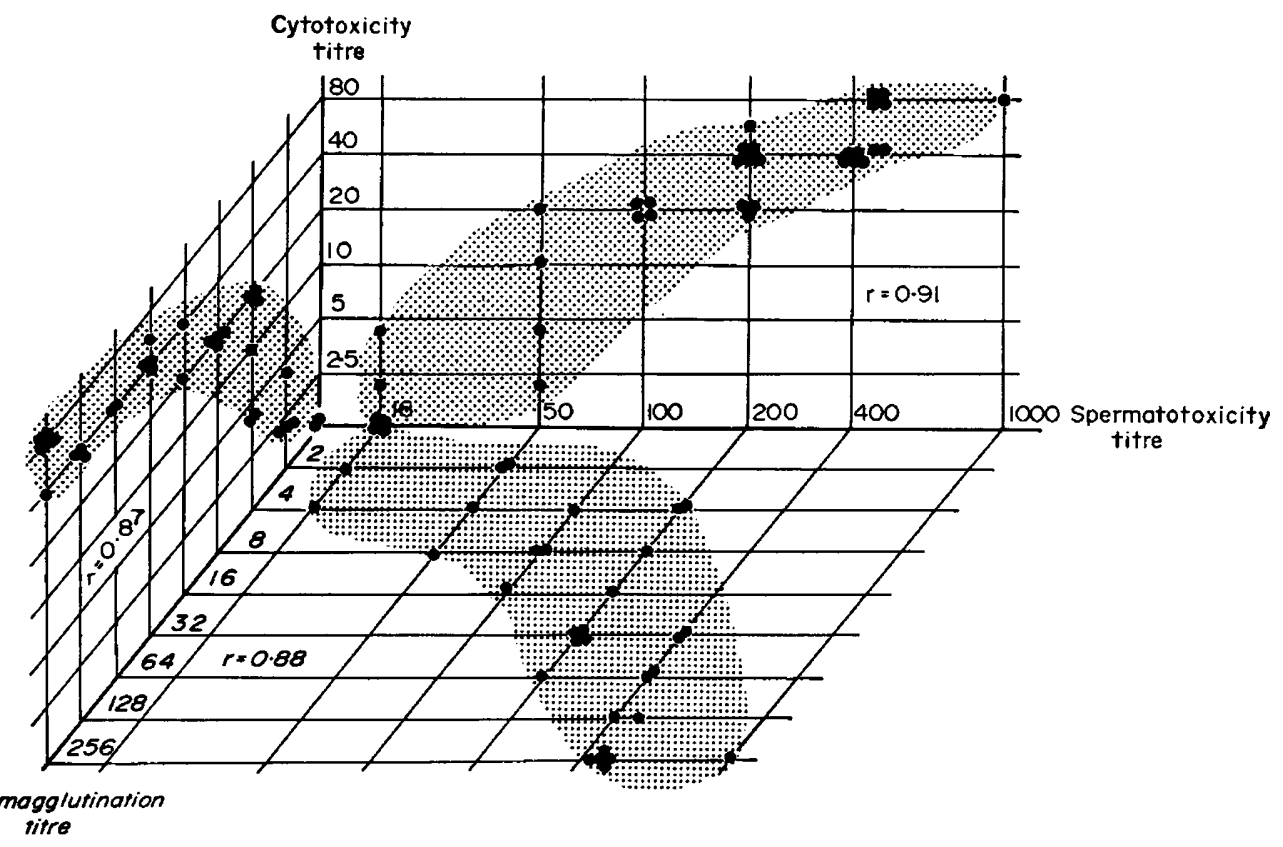

TEXT-FIG. 1. Tridimensional correlations between the guinea-pig serum titres for the three studied biological properties. This representation in perspective presents the correlation cloud in three dimensional space, the three punctate areas being orthogonal projections of it.

doses $\left(\bumpeq 1.5 \times 10^{10}\right.$ for $\mathrm{S}$ and $\bumpeq 1.6 \times 10^{10}$ for $\left.\mathrm{P}\right)$; with kidney homogenate $(1 \mathrm{~g})$, liver homogenate $(1 \mathrm{~g})$ and ground spleen cells $\left(10^{9} \mathrm{cells}\right)$.

It was noted that more autoantigen $T$ was necessary to decrease the spermatotoxic than the cytotoxic titre of a given serum (as seen in Table 4): $\bumpeq 10^{9}$ spermatozoa of autoantigen $T$ reduced the cytotoxic titre by a factor of at least eight times (and probably over sixteen times) while spermatotoxic titres were only reduced by a half.

Relations and correlations between the three antibody activities

If antibodies of the same specificity (and assuming that they are of the same immunoglobulin class or at least that there are not important differences) are responsible for the three activities, a correlation should exist between the titres of the three properties and a relation between their simultaneous presence or absence (the only difference being attributable to the sensitivity of detection assuming perfect techniques). 
Thirty-three sera were studied in this respect, the three techniques being studied simultaneously and with a sufficient number of dilutions.

(a) Simultaneous presence of the studied properties. The results are given in Table 5. They show that $100 \%$ of spermagglutinating sera were cytotoxic and that the reverse was true in $96.5 \%$ of the cases, while $88 \%$ of spermatotoxic sera were both cytotoxic and spermagglutinating. Non-spermatotoxic sera were never spermagglutinating or cytotoxic.

(b) Correlations between the antibody titres of the three properties. These correlations are expressed in Text-fig. 1. The coefficient of correlation was $r=0.91$ for spermatotoxicity versus cytotoxicity, 0.87 for cytotoxicity versus spermagglutination and 0.88 for spermagglutination versus spermatotoxicity. For each of these three coefficients, $P$ was $<0.0001$. The partial correlations were computed and gave the following figures: cytotoxicity versus spermatotoxicity/spermagglutination $=0.63 \quad(P<0.01)$, spermagglutination versus spermatotoxicity/ cytotoxicity $=0.44 \quad(P<0.005)$ and spermagglutination versus cytotoxicity/ spermatotoxicity $=0.33$ (N.S.).

\section{DISCUSSION}

Two main lines of discussion are of interest, concerning the techniques utilized and the implications of the results, respectively.

\section{A. Techniques utilized}

Spermatotoxicity. Absence of acrosomes (always preceded by immobilization) is a better criterion of sperm death than immobilization. Guinea-pig spermatozoa have large bright acrosomes, easily seen under a phase-contrast microscope at a magnification not higher than $\times 100$. This allows the observer to make a rapid assessment of the percentage of death (absence of acrosomes) without direct counting and gives reproducible results when proceeding blindly or when taking a base-line largely higher than the controls (usually $10 \%$ ). A $50 \%$ spermatotoxic titre determined in this way is reliable as can be seen from the results obtained.

Spermagglutination. Microscopic techniques such as those utilized for human spermatozoa are tedious to apply and not easily adapted to guinea-pig spermatozoa since these are subject to microagglutination even in diluted guinea-pig serum. Two macroscopic techniques are known: the first was proposed by Kibrick, Belding \& Merrill (1952) and performed in tubes with gelatine at $37^{\circ} \mathrm{C}$; with this technique, Rümke \& Titus (1970) observed the agglutination of rat spermatozoa mixed with homologous immune sera. The second technique was devised by Shulman \& Heckman (1971) and utilized capillary tubes at $4^{\circ} \mathrm{C}$. As compared by Shulman \& Shulman (1971) and Shulman, Heckman \& Pann (1971), both techniques give closely correlated results in the reaction of guinea-pig spermatozoa with homologous and heterologous immune sera. With the help of A. M. Heckman, a comparison of the preceding techniques together with ours was accomplished on a small number of diverse sera. A reasonably good concordance was found, the main advantage of our technique 
being its simplicity and rapidity. Unlike Kibrick's technique, however, it did not seem to be directly applicable to human spermatozoa.

Cytotoxicity. The main point to be discussed in the classical cytotoxicity test used in our study is the presence in guinea-pig complement (unheated whole serum) of natural spermatotoxic antibodies, the activity of which is thermolabile (Spooner, 1964; Monastirsky \& Fernandez Collazo, 1968). These are not present in all guinea-pig sera. Their activity usually disappears at a dilution of 2 to 4 except in a few cases, possibly when the testicular cells utilized are in a less good condition than usual (the complement pool is always the same). This 'natural' cytotoxic action is suppressed by adding heated guinea-pig serum. Heating may inhibit the complement-fixing capacity of these natural antibodies that compete with the unheated complement-fixing ones for cell fixation. Whatever the mechanism of action of these heated sera, heated normal serum should be added to the medium at $5 \%$ dilution in order to prevent this cytotoxicity of complement.

\section{B. Implications of the results}

Autoimmune spermatotoxicity has been known since Metalnikoff (1900). More recently, it has been demonstrated by many authors (Voisin, Delaunay \& Barber, 1951; Freund, Lipton \& Thompson, 1953; Voisin, Toullet \& Maurer, 1958; Baum, Boughton, Mongar \& Schild, 1961; Brown, Glynn \& Holborow, 1963; Mancini, Monastirsky, Fernandez Collazo, Seiguer \& Alonso, 1969; Johnson, 1970). Autoimmune spermagglutination has also been studied (Shulman et al., 1971) as well as cytotoxicity for testicular cells (Chutná \& Rychlíková, 1964; Chutná \& Pokorná, 1967; Mancini et al., 1969; Johnson, 1970). The responsible antigen or antigens had not, however, been identified and guinea-pig spermatozoa possess at least four autoantigens.

1. From the results, it is clear that spermatotoxicity, spermagglutination and testicular cell cytotoxicity all depend on the same antigen-antibody system, since whatever the immunization procedure and antigen, the three activities observed in the sera are strongly linked (in their presence or absence) and correlated (in their active titres). In spite of the excellent correlation observed between these activities, a few differences were also observed.

Between spermatotoxicity and spermagglutination. The higher sensitivity of the spermatotoxicity test is understandable since a small amount of complementfixing antibodies is sufficient to lyse a cell bearing the corresponding antigen, while more antibodies are required to cause agglutination of the same type of cells. On the other hand, spermatotoxicity can only be caused by complementfixing antibodies such as IgM and $\operatorname{IgG}_{2}$ (guinea-pig) while spermagglutination may be caused by non-complement-fixing antibodies. Since one of the studied spermatozoa autoantigens $(\mathbf{T})$ is insoluble, it was impossible to test the presence of $\mathrm{IgG}_{1}$ anaphylactic antibodies by PCA. It was possible, however, to show the existence of non-spermatotoxic, spermagglutinating $\mathrm{IgG}_{1}$ anti- $\mathrm{T}$ antibodies by column chromatography. These differences in the sensitivity of the tests and in the classes of responsible antibodies may satisfactorily account for the imperfect correlations between spermatotoxicity and spermagglutination in the sera.

Between spermatotoxicity and cytotoxicity. Complement-fixing antibodies only may 
be responsible for both effects. The two types of cells do, however, behave slightly differently from each other in two respects. Much more antibody is necessary to kill testicular cells than to kill spermatozoa and for a given serum the cytotoxic titre is reduced by smaller amounts of autoantigen $T$ than the spermatotoxic titre. This might be due to a smaller quantity of the antigen present on the surface of the testicular cells than on that of the spermatozoa, resulting in the above discrepancies. The quantity of surface antigen involved in spermatotoxicity has been compared (Johnson, 1970) by cytotoxicity absorption tests and found to be smaller on spermatids than on spermatozoa.

2. It seems clear from the results that the only autoantigen/autoantibody system involved in spermatotoxicity, spermagglutination and cytotoxicity of immature sperm cells is the autoantigen $\mathrm{T} /$ anti-T antibody system. Besides sera from guinea-pigs immunized against autologous whole spermatozoa, only anti-T sera (and all of them after hyperimmunization) possessed the three properties. These properties can be completely absorbed from immune sera by autoantigen $\mathrm{T}$ (as well as by whole spermatozoa) but not by the $\mathrm{S}$ or $\mathrm{P}$ autoantigens. Autoantigens $\mathrm{S}$ and $\mathrm{P}$ give rise to autoantibodies endowed with the properties cited in 'Materials and Methods' but not with the three activities under study. No castrated animal immunized or hyperimmunized with $\mathrm{S}$ or $\mathrm{P}$ gave rise to spermatotoxic or cytotoxic antibodies. The reason why a few intact animals gave rise to antibodies (of low titres) of this type was presumably the result of S- (or P-) induced testicular lesions (AIAO) liberating some $\mathrm{T}$ which was able to immunize guinea-pigs even in the absence of adjuvants. The evidence for this lies in the fact that whole spermatozoa (that contain $\mathrm{S}, \mathrm{P}$ and $\mathrm{T}$ ) could absorb the spermatotoxic activity found in an anti-P serum (anti-S has not been studied in this respect), while soluble extracts (that contain $\mathrm{S}$ and $\mathrm{P}$ but not $\mathrm{T}$ ) could not. The reason for the unexpected spermagglutinating activity (at low dilutions) of $13 \%$ of anti-P sera although $\mathrm{P}$ is known not to be a surface antigen (Toullet et al., 1970, 1973) might be due to the boosting of natural autoantibodies (sometimes present and slightly active at low dilutions) by immunization procedures.

Some kind of allotypic antigen, like the histocompatibility $(\mathrm{H})$ antigens, might be regarded as responsible for the observed results for the following four reasons: H-2 antigens have been described on mouse spermatozoa (Vojtišková, Poláčková \& Pokorná, 1969); corresponding alloantibodies have been shown to be spermatotoxic (Fellous \& Dausset, 1970; Johnson \& Edidin, 1972); H antigens are surface antigens with various properties and behaviour analogous to that of $\mathrm{T} ; \mathrm{T}$ preparations come from hundreds of outbred guinea-pigs. This possibility can be eliminated with confidence on the following grounds: anti-T activity is found in sera from guinea-pigs immunized with their own spermatozoa alone, and spleen cells obtained from the same animal that gives the spermatozoa and immature sperm cells for the cytotoxicity tests are not able to absorb the spermatotoxic and cytotoxic ability of the studied sera.

3 . The characteristics of this autoantigen $T$ are in agreement with the three properties under study: it has been shown to fix complement with corresponding immune sera (Voisin \& Toullet, 1968) and is situated at the surface of the acrosomal and cytoplasmic membranes of spermatozoa and spermatids, as 
shown by immunofluorescence and by the fact that only anti- $T$ antibodies are fixed on living spermatozoa (Toullet et al., 1973). This explains the toxic and agglutinating properties of anti-T antibodies. It is possible that more immature cells (spermatocytes) contain autoantigen $\mathbf{T}$ and are lysed by anti- $\mathrm{T}$ plus complement, although the work by Mancini et al. (1969) suggests that immune sera against homologous testis are not cytotoxic for spermatogonia and spermatocytes. Autoantigens $\mathrm{S}$ and $\mathrm{P}$ are present in the acrosomes and proacrosomal granules but anti-S and anti-P antibodies are not fixed on living spermatozoa. This explains the absence of spermatotoxic, cytotoxic and spermagglutinating activity of anti-S and anti-P antibodies in spite of the fact that the $\mathrm{P} /$ anti-P system is perfectly able to fix complement. The fact that all animals immunized with $\mathrm{T}$ preparations (several injections) and most animals immunized with their own spermatozoa elaborate anti- $T$ antibodies indicates that $T$ is a highly efficient antigen, to which any individual can become immunized.

4. The immunopathological consequences of the preceding properties of the autoantigen $\mathrm{T}$ and of the corresponding antibodies and autoantibodies should not be overlooked. Autoantigen $\mathrm{T}$ is present at the cell surface; it is very efficiently immunogenic; unlike $\mathrm{S}$ and $\mathrm{P}$ it is highly insoluble and therefore not diffusible. It cannot therefore diffuse outside the seminiferous tract as $\mathrm{S}$ and $\mathbf{P}$ can do, but, unlike $S$ and $P$, it renders living spermatozoa susceptible to the action of anti-T autoantibodies. Any hypothesis on the mechanism of AIAO must take this fact into account. The only experiments made with purified sperm autoantigens ( $\mathrm{S}, \mathrm{P}$ and $\mathrm{T}$ ) have demonstrated that the three of them are able to induce specific lesions of AIAO which are indistinguishable from each other when complete; the first lesions, however, seem to present differences indicating different mechanisms for their origin (Voisin \& Toullet, $1968,1971)$. In particular, animals treated with $T$, often show some degree of aspermatogenesis before any significant cellular infiltration.

\section{ACKNOWLEDGMENT}

This work was carried out with the technical participation of Mme Françoise Chadenier.

\section{REFERENGES}

Baum, J., Boughton, B., Mongar, J. L. \& Schild, H. O. (1961) Autosensitization by sperm in guinea pigs. Immunology, 4, 95.

Brown, P. G., Glynn, L. E. \& Holborow, E. J. (1963) The pathogenesis of experimental allergic orchitis in guinea pigs. F. Path. Bact. 86, 505.

Chutná, J. \& PoKorná, Z. (1967) IgM and IgG antibodies after immunization with organ-specific testicular antigen. Folia biol., Praha, 13, 68.

Chutná, J. \& Rychlíxová, M. (1964) A study of the biological effectiveness of antibodies in the development and prevention of experimental autoimmune aspermatogenesis. Folia biol., Praha, $10,188$.

Fellous, M. \& Dausset, J. (1970) Probable haploid expression of HLA antigens on human spermatozoa. Nature, Lond. 225, 191.

Freund, J., Lipton, M. M. \& Thompson, G. E. (1953) Aspermatogenesis in the guinea pig induced by testicular tissue and adjuvants. $\mathcal{7}$. exp. Med. 97, 711.

Johnson, M. H. (1970) Selective damage to spermatogenic cells of high antigenicity during autoallergic aspermatogenesis. F. Pathol. 102, 131.

Johnson, M. H. \& Edidin, M. (1972) H-2 antigens on mouse spermatozoa. Transplantation, 14, 781. 
Kibrick, S., Belding, D. L. \& Merrill, B. (1952) Methods for the detection of antibodies against mammalian spermatozoa. I. A modified macroscopic agglutination test. Fert. Steril. 3, 419.

Mancini, R. E., Monastirsky, R., Fernandez Collazo, E., Seiguer, A. G. \& Alonso, A. (1969) Cytotoxic effect of antispermatic antibodies on guinea pig germinal cells in vitro. Fert. Steril. 20, 779.

Metalnikoff, S. (1900) Etudes sur la spermotoxine. Annls Inst. Pasteur, Paris, 14, 577.

Monastirsky, R. \& Fernandez Gollazo, E. L. (1968) Effet cytotoxique de sérums normaux, autologues, homologues et hétérologues sur les cellules germinatives du cobaye. C. r. Séanc. Soc. Biol. $162,291$.

RüMKE, P. \& Titus, M. (1970) Spermagglutinin formation in male rats by subcutaneously injected syngeneic epididymal spermatozoa and by vasoligation or vasectomy. $\mathcal{J}$. Reprod. Fert. 21, 69.

Shulman, S. \& Heckman, A. (1971) Antibodies to spermatozoa. I. A new macroscopic agglutination technique for their detection, using immotile sperm. Clin. exp. Immun. 9, 137.

Shulman, S., Hegkman, A. \& Pann, C. (1971) Antibodies to spermatozoa. II. Spermagglutination techniques for guinea-pigs and human cells. F. Reprod. Fert. 27, 31.

Shulman, S. \& Shulman, J. F. (1971) Spermagglutinating activity in man and guinea pig. Fert. Steril. 22, 633.

SPOoner, R. L. (1964) Gytolytic activity of the serum of normal male guinea pigs against their own testicular cells. Nature, Lond. 202, 915.

Toullet, F. \& Vorsin, G. A. (1969) Réactions d'hypersensibilité et anticorps sériques envers les autoantigènes de spermatozoïdes. Relations avec le mécanisme de l'orchite aspermatogénétique auto-immune. Annls Inst. Pasteur, Paris, 116, 579.

Toultet, F., Vorsin, G. A. \& Nemirovsky, M. (1970) Localisation cytologique et pouvoir pathogène des auto-antigènes de spermatozoïdes chez le cobaye. Annls Inst. Pasteur, Paris, 118, 513.

Toullet, F., Voisin, G. A. \& Nemirovsky, M. (1973) Histo-immuno-chemical localization of three guinea pig spermatozoa autoantigens. Immunolog, 24, 635.

Voisin, G. A., Delaunay, A. \& Barber, M. (1951) Sur des lésions testiculaires provoquées chez le cobaye par iso- et auto-sensibilisation. Annls Inst. Pasteur, Paris, 81, 48.

Vorsin, G. A. \& Toullet, F. (1968) Etude sur l'orchite aspermatogénétique autoimmune et les autoantigènes de spermatozoïdes chez le cobaye. Annls. Inst. Pasteur, Paris, 114, 727.

Vorsin, G. A. \& Toullet, F. (1969a) Studies on spermatozoa autoantigens in the guinea pig. In Immunology of Spermatozoa and Fertilization, p. 149. Bulgarian Academy of Sciences Press, Varna, Bulgaria.

Vorsin, G. A. \& Toullet, F. (1969b) Relation between hypersensitivity responses to autoantigens and tissue damage in the male reproductive tract. In Immunology and Reproduction, p. 93. Int. Planned Parenthood Fedn, London,

Vorstn, G. A. \& Toullet, F. (1971) Autoimmune aspermatogenic orchitis (A.I.A.O.). A model for three possible mechanisms of autoimmune lesions. Folia allergol. 18, 310.

Voisin, G. A., Toullet, F. \& Maurer, P. (1958) The nature of tissular antigens, with particular reference to autosensitization and transplantation immunity. Ann. N.Y. Acad. Sci. 64, 1053.

VojtíśKová, M., PoláčKovÁ, M. \& PoKorná, Z. (1969) Histocompatibility antigens on mouse spermatozoa. Folia biol., Praha, 15, 322. 